\title{
Introduction to Correlation of Precambrian Rock Sequences
}

GEOLOGICAL SURVEY PROFESSIONAL PAPER 1241-A

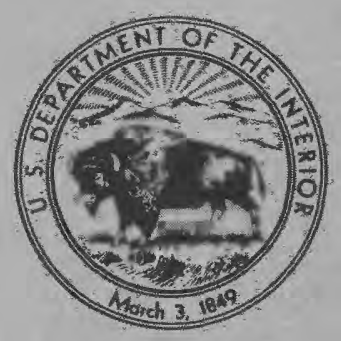




\section{Introduction to Correlation of Precambrian Rock Sequences}

By JACK E. HARRISON and ZELL E. PETERMAN

CORRELATION OF PRECAMBRIAN ROCKS OF THE UNITED STATES AND MEXICO

Edited by JACK E. HARRISON and ZELL E. PETERMAN

GEOLOGICAL SURVEY PROFESSIONAL PAPER 1241-A

An introduction to interregional

correlation, emphasizing the

need for charts based on

isotopic data

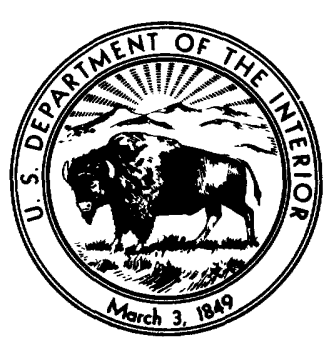

UNITED STATES GOVERNMENT PRINTING OFFICE, WASHINGTON : 1984 


\title{
UNITED STATES DEPARTMENT OF THE INTERIOR
}

\author{
WILLIAM P. CLARK, Secretary
}

\author{
GEOLOGICAL SURVEY
}

Dallas L. Peck, Director

First Printing 1984

Second Printing 1984

Library of Congress Cataloging in Publication Data

Harrison, Jack Edward, 1924-

Introduction to Correlation Precambrian Rock Sequences.

(Correlation of Precambrian Rocks of the United States and Mexico) (Geological Survey Professional Paper 1241-A)

Bibliography: 7 p.

Supt. of Docs. no.: I 19.16:1241-A

1. Geological time. 2. Stratigraphic correlation. 3. Geology, Stratigraphic-Precambrian. 4. Geology-United States. 5. Geology-Mexico. I. Peterman, Zell E. II. Title. III. Series. IV. Series: Geological Survey Professional Paper 1241-A

For sale by the Branch of Distribution, U.S. Geological Survey

604 South Pickett Street, Alexandria, VA 22304 


\section{CONTENTS}

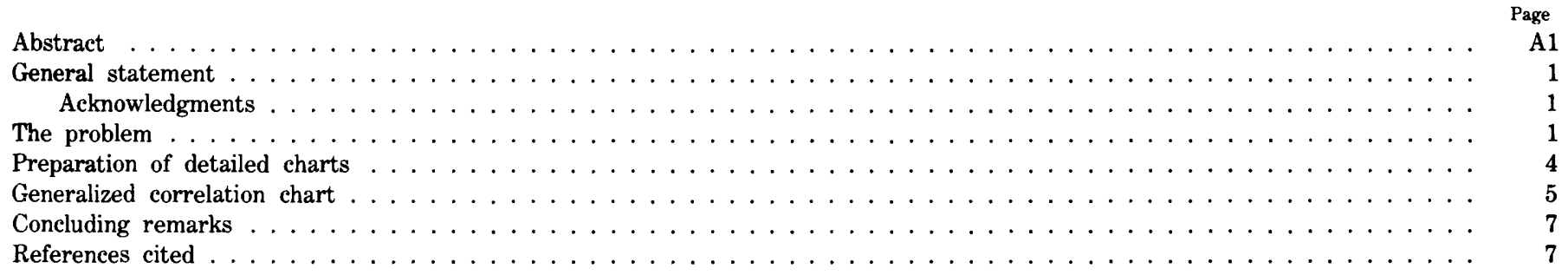

\section{ILLUSTRATIONS}

Plate 1. Generalized correlation chart for the Precambrian of the United States and Mexico

in pocket

FIGURE 1. Generalized outcrop map of Precambrian rocks of Canada, the United States, and Mexico 



\title{
CORRELATION OF PRECAMBRIAN ROCKS OF THE UNITED STATES AND MEXICO
}

\section{INTRODUCTION TO CORRELATION OF PRECAMBRIAN ROCK SEQUENCES}

\author{
By JACK E. HARRISON and Zell E. PETERMAN
}

\begin{abstract}
This introductory chapter on correlation of Precambrian rocks of the United States and Mexico outlines the problem of correlations and emphasizes the need for charts based on isotopic data. The groundrules adapted for preparation of the correlation charts are given and apply to all charts in Professional Paper 1241. A generalized correlation chart for the Precambrian of the United States and Mexico presents state-ofthe-art knowledge on interregional correlations and serves to illustrate some of the difficulties in deriving an acceptable time scale for the Precambrian on a continent-wide or world-wide basis.
\end{abstract}

\section{GENERAL STATEMENT}

This and subsequent chapters of Professional Paper 1241 summarize present knowledge of Precambrian rock sequences of the United States and Mexico, with emphasis on their dating and correlation. The reports have been prepared by the Working Group on the Precambrian for the United States and Mexico, a formal committee of the Subcommission on Precambrian Stratigraphy of the International Union of Geological Sciences (IUGS) Commission on Stratigraphy. This Working Group is one of several groups established throughout the world in 1975 by the Chairman of the IUGS Subcommission, H. L. James, to aid the Subcommission in its analysis of the Precambrian terranes of the world and in its effort to devise an internationally acceptable time scale and nomenclature for the Precambrian.

The character and distribution of major Precambrian units of the conterminous United States have been described by King (1976). Reports from the Working Group are principally concerned with evaluations of fundamental geologic and age data that serve as a basis for correlation, that identify which parts of the Precambrian record are preserved, and that show how much of the record is missing. In addition, the economic importance of various Precambrian rock units is briefly noted, and first summaries of the Precambrian of Alaska and Mexico are presented.

\section{ACKNOWLEDGMENTS}

Working sessions and preparation of charts and reports by the Working Group were supported financially by the U.S. Geological Survey and by grant number 78-095-E from the U.S. Department of Energy. Guidance on stratigraphic questions was generously supplied by Marjorie E. MacLachlan of the U.S. Geological Survey, Denver. M. J. Frarey, Chairman of the IUGS Working Group on the Precambrian for Canada, participated in some of our Working Group sessions. We are also pleased to acknowledge technical advice from two of our Canadian consultants, G. H. Eisbacher, Geological Survey of Canada, Vancouver, British Columbia, and Harold Williams, Memorial University, St. John's, Newfoundland.

\section{THE PROBLEM}

Precambrian time encompasses the first seveneighths of Earth history. A series of crust-forming, tectonic, magmatic, sedimentational, biologic, and oreforming events-some of which are unique in Earth history-are recorded in rocks of the Precambrian. Ordering of these events and understanding of the geologic processes that formed the rocks is essential to comprehension both of the architecture and of the resources of the Earth.

Study of the Precambrian in the United States and Mexico is complicated not only by the changes produced by deformation and metamorphism but also by the extensive cover of Phanerozoic rocks that obscure large terranes of Precambrian from direct view. The general isolation of individual terranes of Precambrian rocks is illustrated on the tectonic map of North America (King, 1969) and by figure 1 of King's (1976) summary of the Precambrian geology of the United States. A simplified geologic map of the United States, Canada, and Mexico (fig. 1) also shows how disconnected the Precambrian 


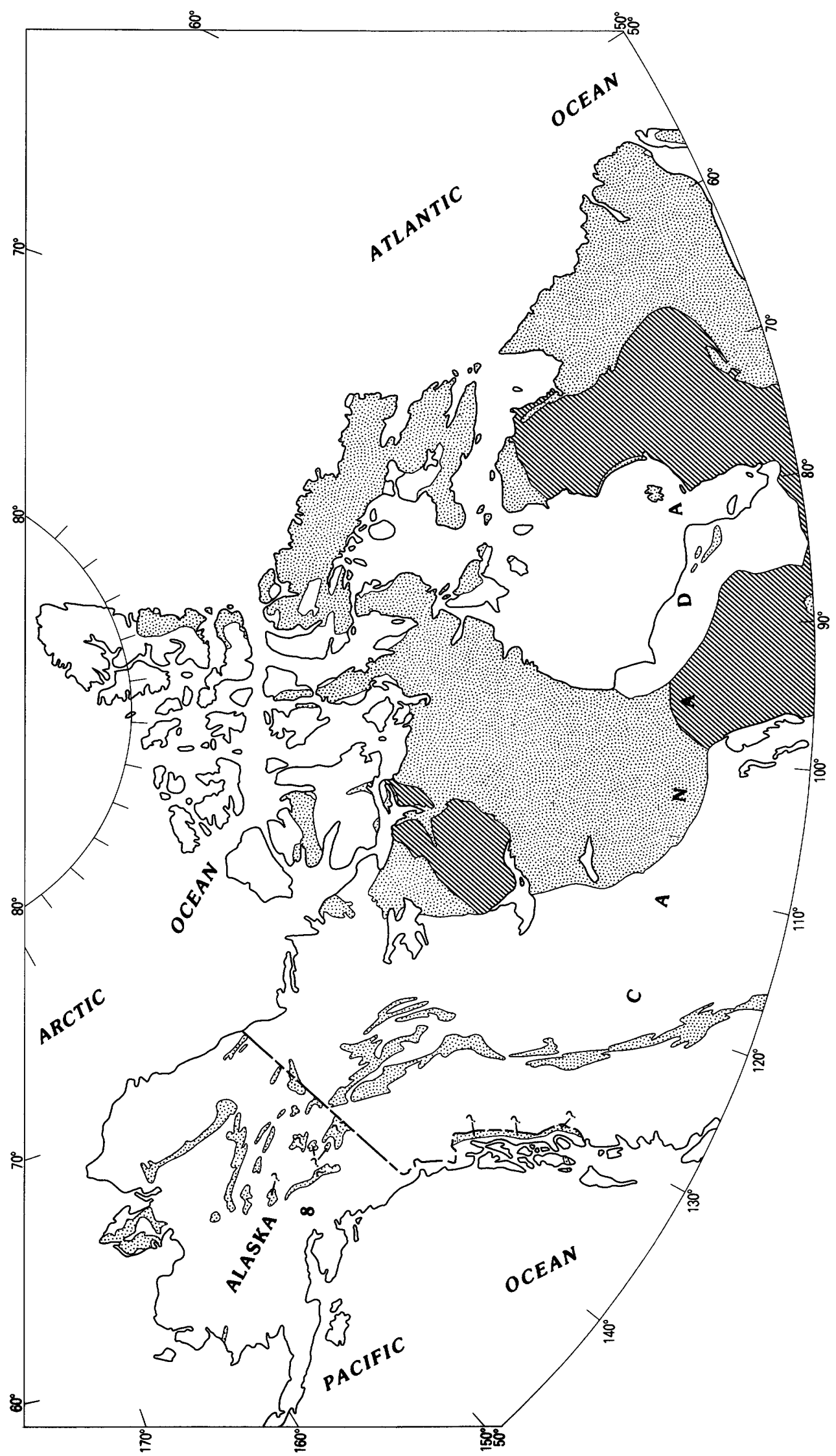




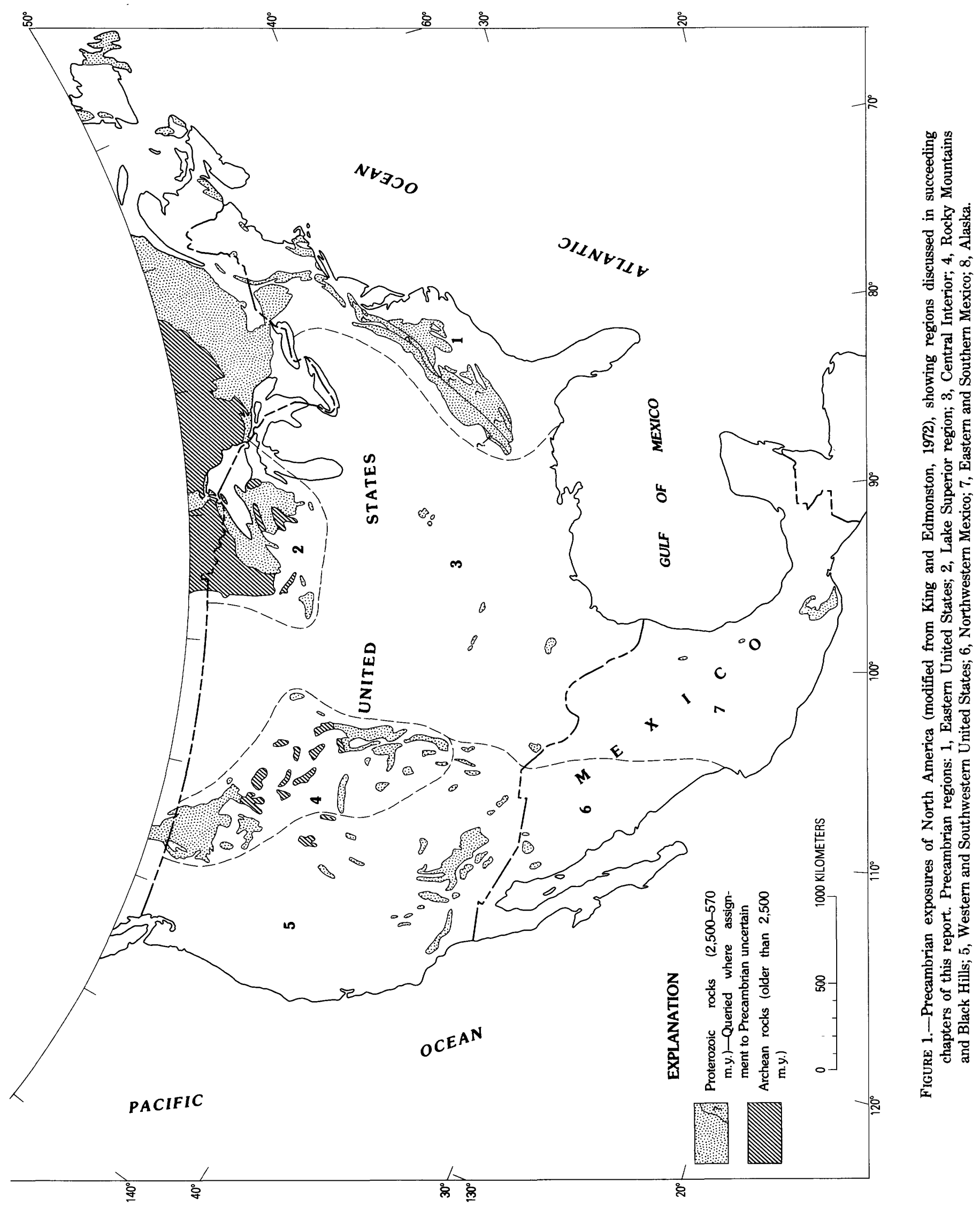


exposures are outside of the shield area of Canada. Summaries of the Precambrian of Canada are contained in reports of the Geological Survey of Canada, notably Douglas (1970).

Though relative ordering of the Precambrian rock units and events in many of the isolated Precambrian outcrop areas can be accomplished through careful geologic mapping, correlation and chronologic ordering among isolated Precambrian terranes in a region is almost totally dependent on credible isotopic dating of rock units. This dependence on isotopic dating stems from the complexities of many highly deformed metamorphic and plutonic terranes. Such terranes cannot be analyzed by normal stratigraphic procedures that depend on superposition of strata for ordering and on homotaxis for correlation between separated areas of exposure. Most Precambrian rocks, particularly the rocks of mid-Proterozoic (about 1600 m.y.) age or older, lack fossils that have meaningful stratigraphic application. Correlation of terranes on a continental or global scale must be done by comparing isotopic ages of rock sequences, or more rarely, by comparing fossil or paleomagnetic data that have been calibrated in isotopically well dated rock sequences.

Understanding of the geologic history of the Precambrian requires placing each of the isolated terranes in its proper time frame, and then comparing terranes to establish the full extent of regions that have been subjected to similar geologic processes and sequences of events. The time frame of seemingly parallel sequences of events may differ from region to region. On a global scale, for example, the termination of sequences of events that characterize the older parts of shield areas and that have been used to define the Archean actually range in age from about $2800 \mathrm{~m}$.y. in some shields to about 2300 m.y. in others (Cloud, 1976). Thus Archean as a time term as used in the past was found to inhibit orderly scientific communication, as the time span intended by the user could vary by $500 \mathrm{~m}$.y. To avoid such confusion, the IUGS Subcommission has recommended a boundary at $2500 \mathrm{~m}$.y. to separate the Archean from the younger Proterozoic (James, 1978).

Continent-wide correlation of the Precambrian has also been fraught with severe problems. Time terms such as early and late Precambrian have been used to identify relative ages of rock assemblages in local terranes. As the number of isotopically dated rocks has increased, it has become evident that such terminology is more confusing than helpful in understanding Precambrian history, because the so-called late Precambrian of one area has turned out to be the so-called early Precambrian in another. In addition, workers have established some time brackets by defining a tectonomagmatic event in a local area, or a time boundary has been established at the termination of such an event, and then a time term has been extended to any rocks of that age whether they participated in that event or not. Such a procedure tends to obscure rather than elucidate Precambrian geologic history.

Detailed correlation charts for the Precambrian of the United States and Mexico presented in subsequent chapters of Professional Paper 1241 represent the state of knowledge on chronometric dating of the major Precambrian terranes. Some reports incorporate previously unpublished data, and all represent an intensive review of the literature and the best judgment of the authors on the quality of geologic and geochronologic data currently available. The charts and reports should serve not only as a source of current data, but also as a tool for testing geologic hypotheses and developing meaningful time terms for the Precambrian of the area covered.

\section{PREPARATION OF DETAILED CHARTS}

For the purpose of describing time-rock relations of the Precambrian, seven more or less coherent regions containing Precambrian terranes (fig. 1) were defined, and small groups of specially qualified geologists and geochronologists were enlisted to prepare the reports. Participants in the regional compilations were as follows:

Eastern United States-D. W. Rankin, James McClelland, R. E. Zartman, A. L. Odom, and T. W. Stern

Lake Superior Region-G. B. Morey, S. S. Goldich, P. K. Sims, and W. R. Van Schmuss

Central Interior-R. E. Denison, E. G. Lidiak, M. E. Bickford, and E. B. Kisvarsanyi

Rocky Mountains and Black Hills-C. E. Hedge, R. L. Houston, Ogden Tweto, Z. E. Peterman, J. E. Harrison, and R. R. Reid

Western and Southwestern United States-L. T. Silver, C. A. Anderson, M. D. Crittenden, Jr., J. C. Crowell, and J. M. Robertson

Northwestern Mexico-T. H. Anderson and L. T. Silver

Eastern and Southern Mexico-Fernando Ortega G., T. H. Anderson, L. T. Silver, and José Guerrero

Alaska-G. D. Eberlein and M. A. Lanphere

Boundaries of the regions (fig. 1) are principally geologic in the sense that they correspond to boundaries of younger geologic provinces, but some reflect political or geographic distinctions, and some are merely convenient from the standpoint of compiling information. The 
boundaries should not be interpreted as fundamental geologic features within the Precambrian basement.

The correlation charts are intended to depict objectively the current state of knowledge of Precambrian rocks and history. Time-rock columns for specific areas portray the record as established from isotopically dated rock bodies and geologically determined sequences. In some areas, one or both of these elements may be lacking, and some units are provisionally placed in the charts through homotaxial or other stratigraphic inferences. Anticipation of any international definition of a time scale for the Precambrian was purposely avoided. Nor were any constraints imposed on the compilations and interpretations from classifications currently in use for Precambrian rocks of North America (for example, James, 1972, or Stockwell, 1973).

The radiometric ages used for constructing the charts and cited in the reports are recalculated, as necessary in terms of the isotopic and decay constants recommended by the IUGS Subcommission on Geochronology (Steiger and Jäger, 1977):

$$
\begin{aligned}
& \text { Uranium } \\
& \lambda\left({ }^{238} \mathrm{U}\right)=1.55125 \times 10^{-10} / \mathrm{yr} \\
& \lambda\left({ }^{235} \mathrm{U}\right)=9.8485 \times 10^{-10} / \mathrm{yr}
\end{aligned}
$$$$
\text { atomic ratio }
$$$$
{ }^{238} \mathrm{U} /{ }^{235} \mathrm{U}=137.88
$$
atomic ratio ${ }^{85} \mathrm{Rb}{ }^{\beta 7} \mathrm{Rb}=2.59265$

Strontium atomic ratios ${ }^{86} \mathrm{Sr} /{ }^{88} \mathrm{Sr}=0.1194$ ${ }^{84} \mathrm{Sr}{ }^{\beta 6} \mathrm{Sr}=0.056584$

Potassium $\lambda\left({ }^{40} \mathrm{~K}_{\beta^{-}}\right)=4.962 \times 10^{-10} / \mathrm{yr}$ $\lambda\left({ }^{40} \mathrm{~K}_{\mathrm{f}}\right)+\lambda\left({ }^{40} \mathrm{~K}_{\mathrm{c}}\right)=0.581 \times 10^{-10} / \mathrm{yr}$

isotopic abundances ${ }^{39} \mathrm{~K}=93.2581$ atom percent ${ }^{40} \mathrm{~K}=0.01167$ atom percent ${ }^{41} \mathrm{~K}=6.7302$ atom percent

Argon atomic ratio ${ }^{40} \mathrm{Ar} /{ }^{36} \mathrm{Ar}$ atmospheric $=295.5$

Format for the detailed charts was designed to help bring out certain types of information. We have tried to convey the degree of certainty or uncertainty of the age of a rock unit or an event. A distinction is made between the length of time for a rock-forming event and the length of time shown as a result of analytical uncertainty, imprecise dating, or geological uncertainty. A distinction is also made between rock units or events dated isotopically and those dated only by stratigraphic procedures.
One feature of the charts deserves special comment. A rock body or event that is poorly dated will commonly occupy a much longer segment of a time-column than those that are accurately dated. For example, a welldated igneous rock body may be depicted as a horizontal line or narrow band bounded by the limits of the uncertainty ( \pm values) of the isotopic age. In contrast, a sequence of metasedimentary rocks may be constrained only within wide limits, such as by much older basement below and much younger rocks or dated events above. The metasedimentary sequence is necessarily depicted as occupying all or most of the time interval between the constraining ages, though in fact it probably occupied only some fraction of that time. This feature serves to identify critical areas and rock units that are in need of additional geologic and geochronologic studies, and emphasizes the inherent difficulties in directly dating sedimentary rocks by radiometric methods. Correlations of these rocks between regions on the basis of homotaxis must consider the probable diachroneity as well as possible total non-equivalence in age of these units.

\section{GENERALIZED CORRELATION CHART}

The summary chart for the United States and Mexico (pl. 1) is a condensed version of the regional charts and was prepared in consultation with the authors of those charts. We assume responsibility for errors in the final compilation, but the chart represents no original work by us.

Several characteristics of the Precambrian of the United States and Mexico are evident on the generalized correlation chart. The long record of Precambrian geologic history found in the Lake Superior region and parts of other regions reflects the long and complicated geologic record characteristic of shield areas, in this case the Canadian Shield. By contrast, the short record seen in the Eastern United States and Alaska has been interpreted as resulting, as least in part, from late Proterozoic and Phanerozoic accretion of marginal fragments from other continents to the North American plate (Rankin, 1976; Lanphere and Eberlein, 1977; Jones and Silberling, 1979; McLelland and Isachsen, 1980; Coney and others, 1980). Likewise, the record of intermediate length found in the Western and Southwestern United States and adjacent parts of Mexico is attributed (L. T. Silver, oral commun. ${ }^{1}, 1979$ ) to cratonization of a block welded to the North American plate about 1600 m.y. ago.

${ }^{1}$ Geological Society of America Presidential Address, "Rattling continental skeletons: arcs and orogenes, cratons and margins, rifts and roots, magmas and metals," 1979. 
The summary chart also illustrates the difficulty in arriving at satisfactory nomenclature for episodes of time in the Precambrian without interposing concepts of local geologic history on those time terms. Two principal methods of subdividing Precambrian time have been used in the past. One method advocated by Hedberg (1974) and recommended by the International Stratigraphic Guide (Hedberg, 1976) is based on stratotypes used to define chronostratigraphic intervals. A second method is based on the length of time, measured isotopically, involved in a local tectono-magmatic event in a type area (a time interval) and establishment of the termination of such an event (a time boundary), for example as proposed by Stockwell (1961, 1973) for the Canadian Shield. The stratotype approach has many deficiencies for most of the Precambrian, as noted several years ago by Trendall (1966). As indicated on the summary chart (pl. 1), much of the Precambrian record involves igneous and high-grade metamorphic rocks that either cannot or may not be subject to normal stratigraphic analysis according to standard procedures and principles. In addition, not only does the scattered sedimentary record fail to represent much of the Precambrian, but also the geologic histories of the various regions where sedimentary rocks do occur may have as many differences as similarities. Thus, selection of a type locality, type section, or stratotype for any part of the Precambrian serves only to identify a time interval or point that may be of only local significance. As geologic and geochronologic studies progress, interregional correlations and generalizations concerning geologic history will become less speculative as they become more constrained by data. We can achieve progress towards a fuller understanding of Precambrian geologic history only by continuing objective geologic and geochronologic investigations and determining, as a fundamental first step, if a rock record representing all parts of the vast span of Precambrian time is preserved and visible.

Tectono-magmatic events are unsatisfactory for interor intra-continental correlation and as a basis for a time scale. A major objection to a scale derived from tectonomagmatic events stems from the inherent difficulty in isotopic calibration of the scale, which requires setting acceptable standards for what constitutes the end of a tectono-magmatic event. General standards applicable to any tectono-magmatic event are almost impossible to define, because time boundaries will change as ages of the events are more accurately determined, as decay and isotopic constants are improved, and as progress in geologic studies leads to a clearer understanding of the processes that caused the events. Also few, if any, such events represent continent-wide or world-wide episodes. Typical of the problems that arise is subdivi- sion of time based on the tectono-magmatic event termed Grenvillian in the Eastern United States and Canada. Current classifications (Stockwell, 1973) place the end of this event at about 1000 m.y., based on $\mathrm{Pb}-\mathrm{U}$ ages. The event is clearly shown on the summary chart (pl. 1) in the Eastern United States by a high-grade metamorphism reflected in several areas of metaigneous and metasedimentary rocks. Just as clearly, this local event has no parallel across most of the continent. The termination of Grenvillian is used in the Stockwell scheme to separate two eras-the Helikian from a younger Hadrynian. The complex geologic history represented within these time intervals in Eastern North America has no direct counterparts in either time frame or kind of rock record in the rest of the United States, in Mexico, and in Western Canada. Thus the time terms and concepts used to define these intervals may be excellent for describing a local geologic history, but they seem quite unsatisfactory in defining time intervals in distant areas.

Other methods for dividing the Precambrian into time units have involved a direct subdivision of time. Goldich (1968) proposed dividing the Precambrian into units of 400 m.y., measuring backwards from $600 \mathrm{~m} . \mathrm{y}$. at least to $3800 \mathrm{~m}$.y. In this system the time intervals were identified only by Greek letters, thus avoiding the problem of using geographic names that might imply geologic concepts of type areas for the time intervals. This logical and systematic approach has not been widely accepted, perhaps because geologists resist a time scale apparently divorced from the rock record. A subsequent scheme (James, 1972) recommended direct division of time but did consider the rock record on a continent-wide basis and chose uneven increments of time because of that record. This latter method has been evaluated by the IUGS Subcommission in terms of its applicability to developing a world-wide time scale for the Precambrian, and some recommendations that have been put forth (James, 1978; Sims, 1979) have been based on such a procedure.

The data shown on the chart (pl. 1) are compatible with the recommendation of the Subcommission on Precambrian Stratigraphy (James, 1978) that the Precambrian be divided into two eons-the Archean and Proterozoic-with the boundary at 2,500 m.y. The Subcommission also called for recommendations on further subdivision of the Precambrian. The Working Group accordingly submitted a preliminary proposal for a time scale for the Precambrian of the United States and Mexico, based on the data in this collection of reports, to the Subcommission and to the North American Commission on Stratigraphic Nomenclature. This proposal (Harrison and Peterman, 1980) stated the philosophy used to arrive at suggestions for subdivision of the Pro- 
terozoic at 900 and 1600 m.y., and of the Archean at 2900 and 3300 m.y. These suggestions, along with those for other Precambrian terranes in the world, formed the basis for a provisional recommendation by the Subcommission (Sims, 1979) for subdivision of the Proterozoic. As the recommendations are provisional, we have not used them on the charts presented in the chapters of Professional Paper 1241.

\section{CONCLUDING REMARKS}

Time-rock charts based primarily on credible isotopic ages for rock bodies are essential for both inter- and intra-continental correlation of Precambrian rocks. Such charts also aid in testing old geologic hypotheses and developing new ones, as long as no genetic time terms or concepts from local geologic histories are superposed on their construction.

A time scale for the Precambrian based on direct division of geologic time appears to have the fewest drawbacks of several schemes used in the past or currently proposed for the Precambrian. Selection of boundaries and terminology for the time intervals presents major problems on a continent-wide and global scale, which require thoughtful consideration. The time-rock charts presented in chapters of Professional Paper 1241 provide basic data required for informed discussions concerning a time scale for the Precambrian.

\section{REFERENCES CITED}

Cloud, P., 1976, Major features of crustal evolution: Geological Society of South Africa, Alex. L. duToit Memorial Lecture Number $14,33 \mathrm{p}$.

Coney, Peter J., Jones, David L., and Monger, James W. H., 1980, Cordilleran suspect terranes: Nature, v. 288, p. 329-333.

Douglas, R. J. W., ed., 1970, Geology and economic minerals of Canada: Geological Survey of Canada Economic Report No. 1, $838 \mathrm{p}$.

Goldich, S. S., 1968, Geochronology in the Lake Superior region: Canadian Journal of Earth Sciences, v. 5, p. 715-724.
Harrison, J. E., and Peterman, Z. E., 1980, Note 52-A preliminary proposal for a chronometric time scale for the Precambrian of the United States and Mexico: Geological Society of America Bulletin, Pt. I, v. 91, no. 6, p. 377-380.

Hedberg, H. D., 1974, Basis for chronostratigraphic classification of the Precambrian: Precambrian Research, v. 1, no. 3, p. 165-177.

- ed., 1976, International stratigraphic guide: New York, John Wiley, $200 \mathrm{p}$.

James, H. L., 1972, Note 40-Subdivision of the Precambrian-an interim scheme to be used by the U. S. Geological Survey: American Association of Petroleum Geologists Bulletin, v. 56, p. $1128-1133$.

-1978, Subdivision of the Precambrian-A brief review and a report on recent decisions by the Subcommission on Precambrian Stratigraphy: Precambrian Research, v. 7, no. 3, p. 193-204.

Jones, D. L., and Silberling, N. J., 1979, Mesozoic stratigraphy, the key to tectonic analysis of southern Alaska: U.S. Geological Survey Open-file Report OF-79-1200.

King, P. B. 1969, Tectonic map of North America: U.S. Geological Survey Map.

-1976, Precambrian geology of the United States - an explanatory text to accompany the Geologic Map of the United States: U.S. Geological Survey Professional Paper 902, 85 p.

King, P. B., and Edmonston, G. J., 1972, Generalized tectonic map of North America: U.S. Geological Survey Miscellaneous Investigations Map I-688.

Lanphere, Marvin A., and Eberlein, G. Donald, 1977, Precambrian terranes of Alaska: Geological Society of America Abstracts with Programs, v. 9, no. 7, p. 1066.

McLelland, James, and Isachsen, Yngvar, 1980, Structural synthesis of the southern and central Adirondacks-A model for the Adirondacks as a whole and plate-tectonics interpretationsSummary: Geologicál Society of America Bulletin, Pt. I, v. 91, no. 2 , p. $68-72$.

Rankin, D. W., 1976, Appalachian salients and recesses-late Precambrian continental breakup and the opening of the Iapetus Ocean: Journal of Geophysical Research, v. 81 , no. 32, p. 56055619.

Sims, P. K., 1979, Precambrian subdivided: Geotimes, v. 24, no. 12, p. 15.

Steiger, R. H., and Jäger, E., 1977, Subcommission on Geochronology-Convention on the use of decay constants in geo- and cosmochronology: Earth and Planetary Science Letters, v. 36, p. 359-362.

Stockwell, C. H., 1961, Structural provinces, orogenies, and time classification of rocks of the Canadian Shield, in Age determinations by the Geological Survey of Canada: Geological Survey of Canada Paper 61-17, p. 108-118.

1973, Revised Precambrian time-scale for the Canadian Shield: Geological Survey of Canada Paper 72-52, 4 p.

Trendall, A. F., 1966, Towards rationalism in Precambrian stratigraphy: Geological Society of Australia Journal, v. 13, p. 517-552. 